\title{
A New Digital Accelerograph Network for El Salvador
}

\author{
J.J. Bommer, ${ }^{1}$ A. Udías, ${ }^{2}$ J.M. Cepeda,${ }^{3}$ J.C. Hasbun, ${ }^{3}$ \\ W.M. Salazar, ${ }^{3}$ A. Suárez, ${ }^{4}$ N.N. Ambraseys, ${ }^{1}$ E. Buforn, ${ }^{2}$ J. Cortina, ${ }^{3}$ \\ R. Madariaga, ${ }^{5}$ P. Méndez, ${ }^{3}$ J. Mezcua,${ }^{4}$ and D. Papastamatiou ${ }^{6}$
}

\section{INTRODUCTION}

There are few countries whose geography and history have been so affected by earthquake and volcanic activity as $\mathrm{El}$ Salvador, the smallest republic in Central America (Figure 1). The capital, San Salvador (Figure 2), has the unenviable claim of being the Latin American city most frequently damaged by earthquakes. Since 1700, San Salvador has been severely damaged by earthquakes on at least 14 occasions (Harlow et al., 1993). The last destructive earthquake to affect San Salvador occurred on 10 October 1986, causing about 1,500 deaths and extensive damage over much of the city, as well as an economic loss equivalent to $31 \%$ of El Salvador's GNP (Coburn and Spence, 1992).

El Salvador has been the focus of several studies of seismicity and seismic hazard, and the San Salvador earthquake of October 1986 generated renewed interest in the area. Three major hazard studies have produced seismic zonifications of El Salvador and a fourth has been carried out at a regional level in Central America. The studies for El Salvador have been carried out by the US Geological Survey (Algermissen et al., 1988), Stanford University (Alfaro et al., 1990) and the Universidad Nacional Autónoma de México (Singh et al., 1993). The Central American study has been produced as part of the collaborative research effort among the Centro de Coordinación para la Prevención de Desastres en América Central (CEPREDENAC), the University of Bergen, and NORSAR (Rojas et al., 1993; Lindholm et al., 1995; Güendel and Bungum, 1995). Figure 3 shows the 475-year return-period accelerations presented in these four studies, and it can be seen that there are very considerable differences in the results obtained. The study by Rojas $e t a l$. (1993) only presents hazard estimates for selected locations,

1. Imperial College of Science, Technology \& Medicine, London, England. 2. Universidad Complutense, Madrid, Spain.

3. Universidad Centroamericana "José Simeón Cañas," San Salvador, El Salvador.

4. Instituto Geográfico Nacional, Madrid, Spain.

5. Institut du Physique de Globe, Paris, France.

6. National Technical University, Athens, Greece.

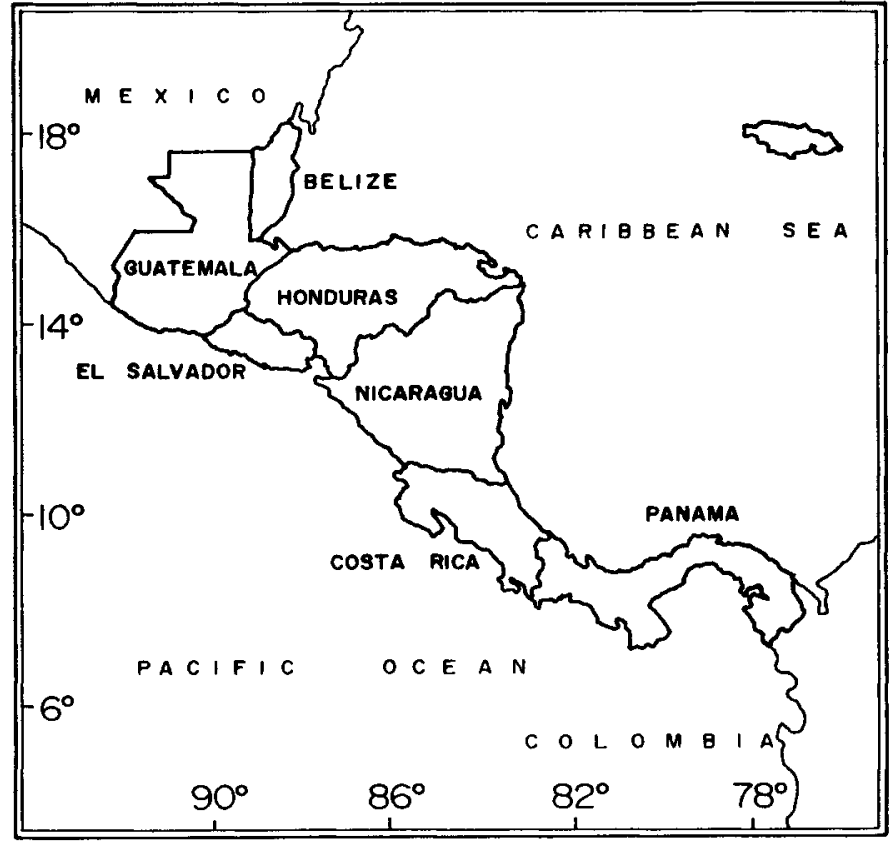

Figure 1. Central America.

and the 475-year acceleration for San Salvador is given as $0.76 \mathrm{~g}$. A comparative review of these seismic hazard assessments by Bommer et al. (1996) highlights the uncertainties associated with the available seismological and geophysical data and the necessity of resolving the more important discrepancies before attempting to produce another zonification of El Salvador.

This article introduces an initiative that is attempting to produce a more reliable database from which a seismic hazard assessment for El Salvador will be carried out. Through contacts established during field investigations of the 1986 San Salvador earthquake, a collaborative research project has been established with support from the International Scientific Cooperation program of the Commission of the European Communities. The partner in the research collaboration in El Salvador is the Universidad Centroamericana 


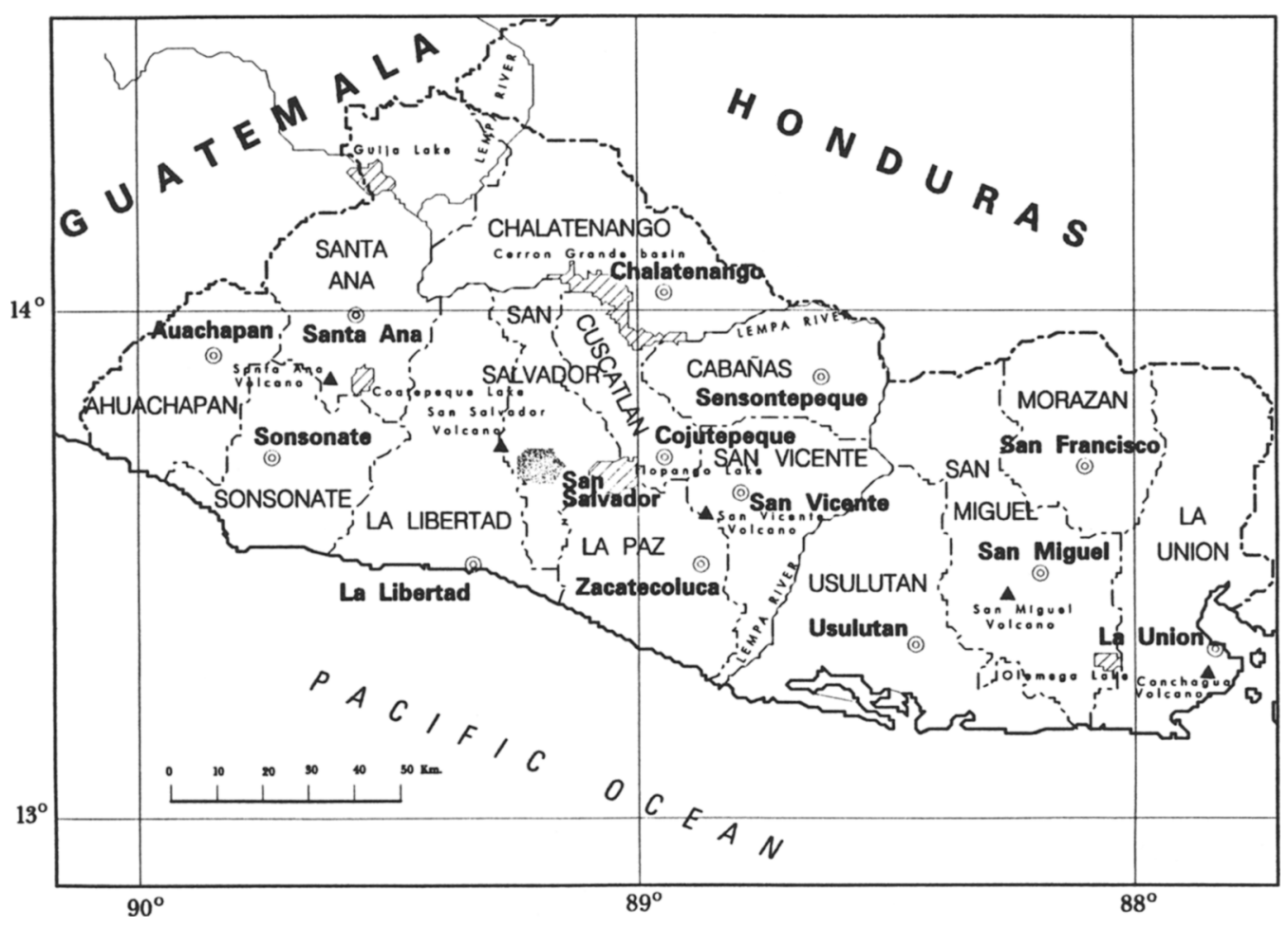

$\Delta$ Figure 2. El Salvador.
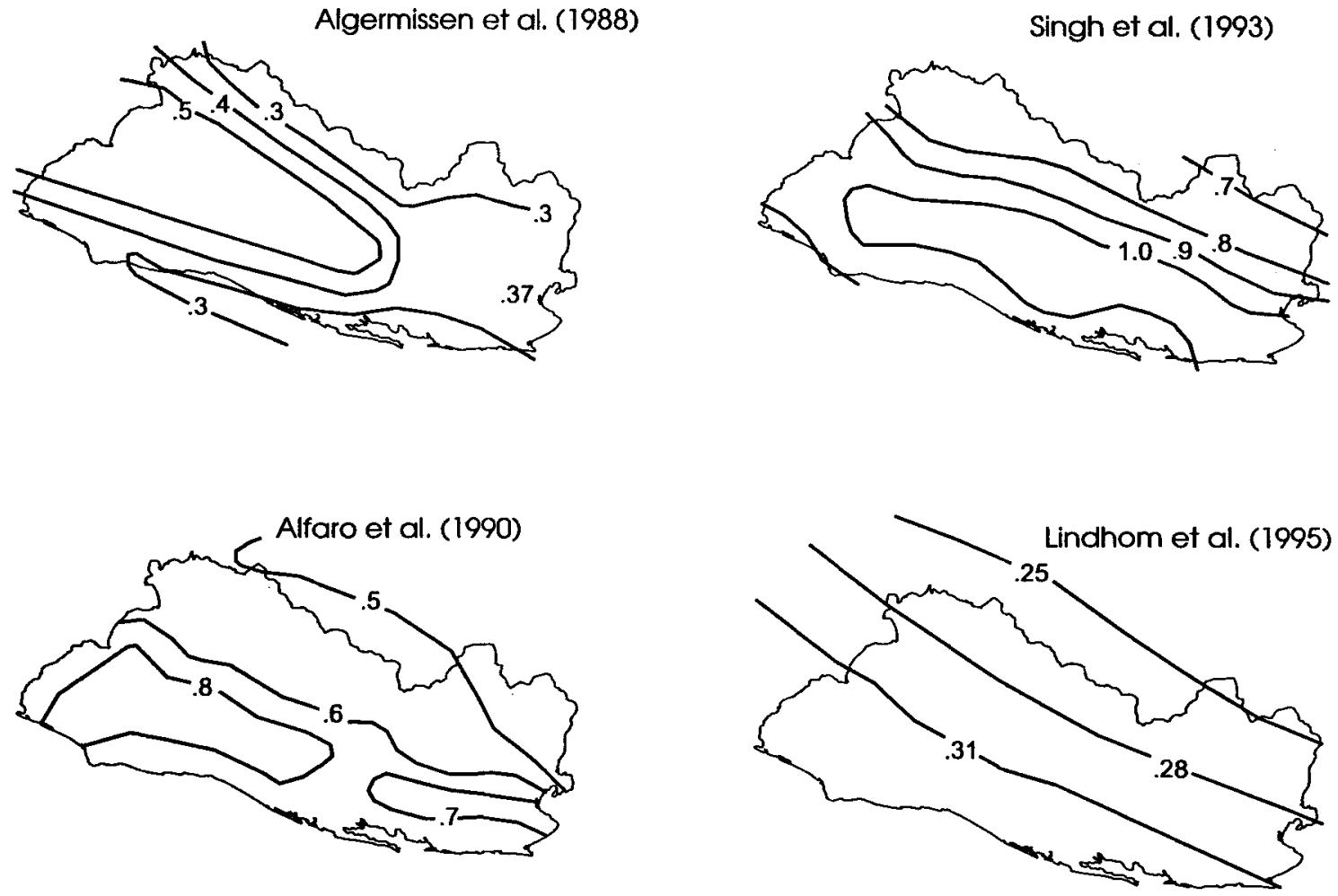

Figure 3. Hazard maps for El Salvador, showing 475-year return period accelerations (as a proportion of the acceleration due to gravity g) from different studies (Bommer, 1996). 
"José Simeón Cañas" (UCA), the second-oldest university in the country, which is run by the Society of Jesus. The project is coordinated by the Universidad Complutense de Madrid (UCM), and the other partners are the Instituto Geográfico Nacional (IGN) in Madrid; Imperial College of Science, Technology and Medicine (ICSTM) in London; the Institut du Physique de Globe (IPG) in Paris; and the National Technical University of Athens (NTUA). The project has a total duration of three years and has two general objectives: to compile reliable seismological and strong-motion databases in order to determine a new zonation of El Salvador with associated seismic design loads, and simultaneously to establish in the UCA a teaching and research capacity in seismology and earthquake engineering. This second objective is of particular importance since prior to the initial work through which this project was established, there was no formal training in these areas in any of the universities in El Salvador. The project will establish earthquake engineering as a central discipline within the curriculum of civil engineering, which is a vital component of any long-term plan for seismic risk mitigation. A major component of the project, which is central to both of the broad objectives, is the installation of a new digital accelerograph nerwork in El Salvador, and it is this aspect of the work that is described in this report.

\section{TECTONICS AND SEISMICITY}

El Salvador is located on the western edge of the Caribbean plate. The rectonics of the region are complex and in some aspects poorly defined, which is reflected in the differences in the delimitation of seismic sources in the hazard studies referred to earlier. The determination of the maximum magnitude for each seismogenic zone is another source of discrepancy among the previous hazard assessments (Bommer et al., 1996).

The subduction of the Cocos plate defines the Middle American Trench, and this thrust interface is a major source of earthquake activity, with steep Benioff-Wadati zones descending to about $300 \mathrm{~km}$. The largest instrumentally recorded earthquakes on this interface have had magnitude of about 8 (Dewey and Suarez, 1991), but the section of the trench off the coast of El Salvador has been shown to have a relatively low seismic slip rate and the largest events this century have had magnitudes between 7.1 and 7.3 (Ambraseys and Adams, 1996). Nonetheless, of the 14 earthquakes that have caused destruction in San Salvador since 1700, only five were directly associated with the subduction of the Cocos plate. The most damaging events are the moderate magnitude, shallow focus earthquakes that coincide with the chain of Quaternary volcanoes that extends from Guatemala to northern Costa Rica. These events reach magnitudes of about 6.5 , but their coincidence with major population centers often results in very severe destruction. Occasionally these events are accompanied by volcanic activity, as was the case in San Salvador in 1917 when the Boquerón volcano last erupted, but generally they are tectonic in origin. The
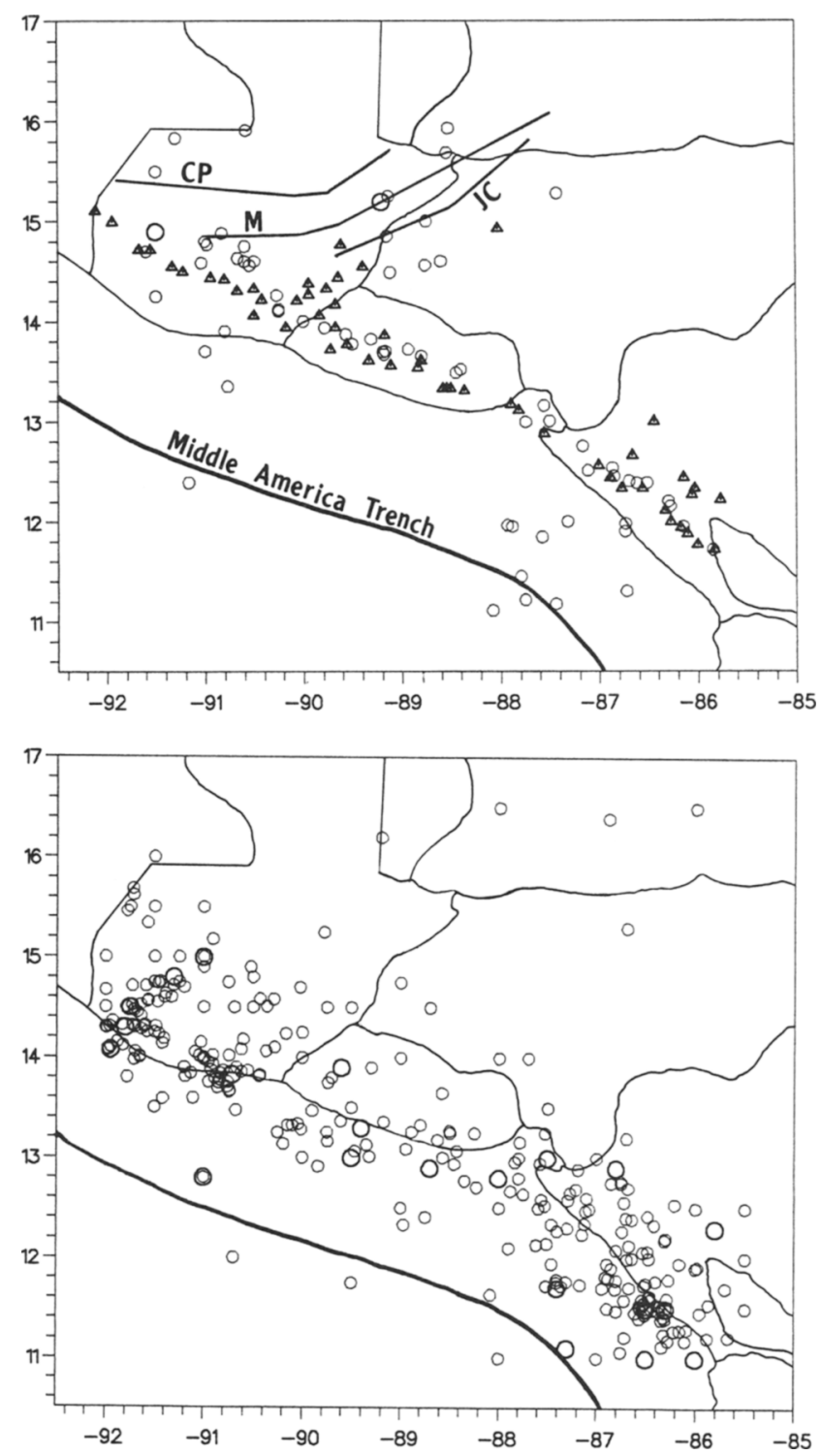

$\Delta$ Figure 4. Seismicity of El Salvador and surrounding areas. Circles show epicenters from 1898 to 1994, small circles are events with magnitude $5.0 \leq M_{s}<7.0$ and large circles $M_{s} \geq 7.0$. Top: upper-crustal seismicity (focal depth $\leq 25 \mathrm{~km}$ ); triangles are volcanoes and straight lines show major faults: $\mathrm{CP}=$ ChixoyPolochic, $M=$ Motagua, $J C=$ Jocotán-Chamelecón. Bottom: earthquakes with focal depth greater than $25 \mathrm{~km}$.

volcanic arc seismicity has been interpreted as resulting from a right-lateral shear zone driven by an oblique component of convergence between the Caribbean and Cocos plates (White, 1991).

The principal tectonic structures and the seismicity of El Salvador and surrounding areas are shown in Figure 4.

\section{STRONG-MOTION DATABASE}

A comparative review of hazard studies carried out for El Salvador (Bommer et al., 1996) has revealed, rather surpris- 

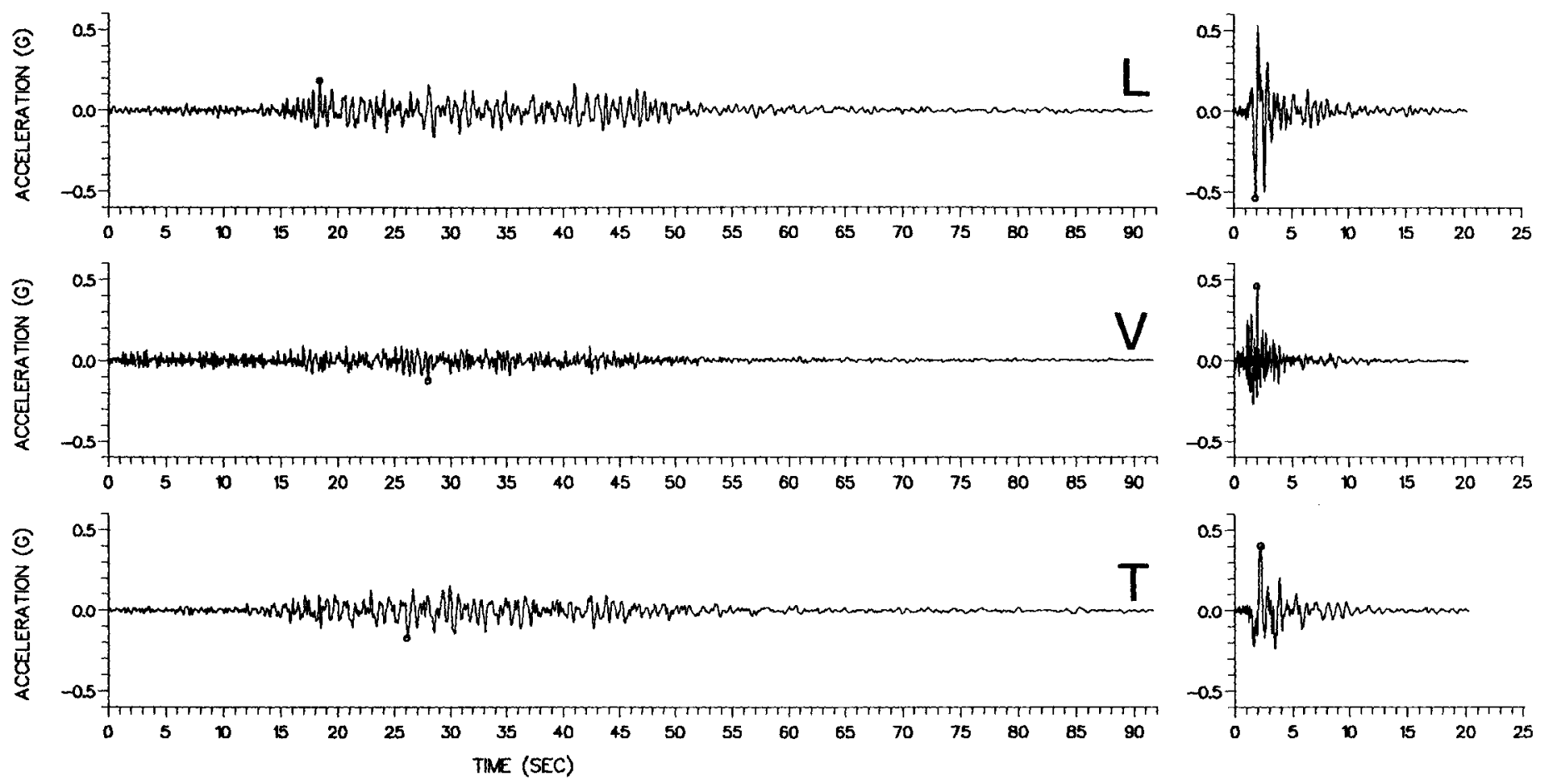

A Figure 5. Strong-motion records obtained in San Salvador from an off-shore earthquake on 19 June 1982 recorded at Observatorio Sismológico (left) and the local earthquake of 10 October 1986 recorded at Instituto Geográfico Nacional (right). $L=$ longitudinal, $V=$ vertical, $T=$ transverse.

ingly, that the attenuation relations for peak acceleration employed in the different studies are quite similar, with the exception of those employed by Lindholm et al. (1995), which predict significantly lower values. Nonetheless, all of the attenuation equations have been based on rather limited and heterogeneous datasets, which include recordings of both upper-crustal earthquakes in the volcanic chain region and events associated directly with the subduction zone. One recent study of strong-motion attenuation characteristics in Central America (Dahle et al., 1995), using a dataset of 280 triaxial accelerograms from throughout Central America and from the Guerrero array in Mexico, concluded that there is no significant difference between the attenuation characteristics of the two types of events. Nonetheless, the intensity distribution of Central American earthquakes suggests that there are differences which in part are obscured by other factors that affect the strong-motion recordings, particularly the soil response. Only one of the hazard studies for El Salvador (Alfaro et al., 1990) has used different attenuation relations for local and subduction zone earthquakes, but each relation was derived from regression on only 20 accelerograms. One aspect of the current research project is the investigation of differences between the recordings from subduction earthquakes and from shallow crustal earthquakes.

Figure 5 shows examples of accelerograms from a subduction event and from a volcanic chain event. The subduction event occurred on 19 June 1982, about $60 \mathrm{~km}$ southwest of San Salvador with a focal depth of $80 \mathrm{~km}$ and surface-wave magnitude $M_{s}=7.3$ (Ambraseys and Adams,
1996). This earthquake was felt throughout most of El Salvador and resulted in 8 deaths and damage to about 1,630 dwellings (Alvarez, 1982). The earthquake also triggered a number of landslides and caused structural damage in some engineered structures (Lara, 1983). The local event occurred on 10 October 1986, just south of San Salvador, with magnitude $M_{s}=5.4$ and focal depth no greater than $8 \mathrm{~km}$ (Harlow et al., 1993). The 1986 earthquake resulted in very intense damage over part of the capital city, resulting in the loss of 1,500 lives and leaving more than 100,000 homeless (Bommer and Ledbetter, 1987; Olson, 1987).

Figure 6 shows the Arias intensities of the combined horizontal and the vertical components from these two recordings. It is interesting to note that they contain almost identical amounts of energy, but in the case of the volcanic chain earthquake most of this energy is contained within about five seconds of strong shaking, whereas for the subduction event the same energy is imparted to structures over about half a minute. This partially explains why the 1986 earthquake was so much more destructive than the 1982 event and why historically volcanic chain events have caused much greater damage than subduction events (White and Harlow, 1993). Figure 7 shows the horizontal and vertical response spectra from the two records, which reveal interesting characteristics. The records are from different sites but both are overlain by layers of volcanic ash, and the similar shapes in Figure 7(a) may reflect the influence of the soil. The spectral amplitudes again indicate why the 1986 event was more destructive. The vertical spectra in Figure $7($ b) and 


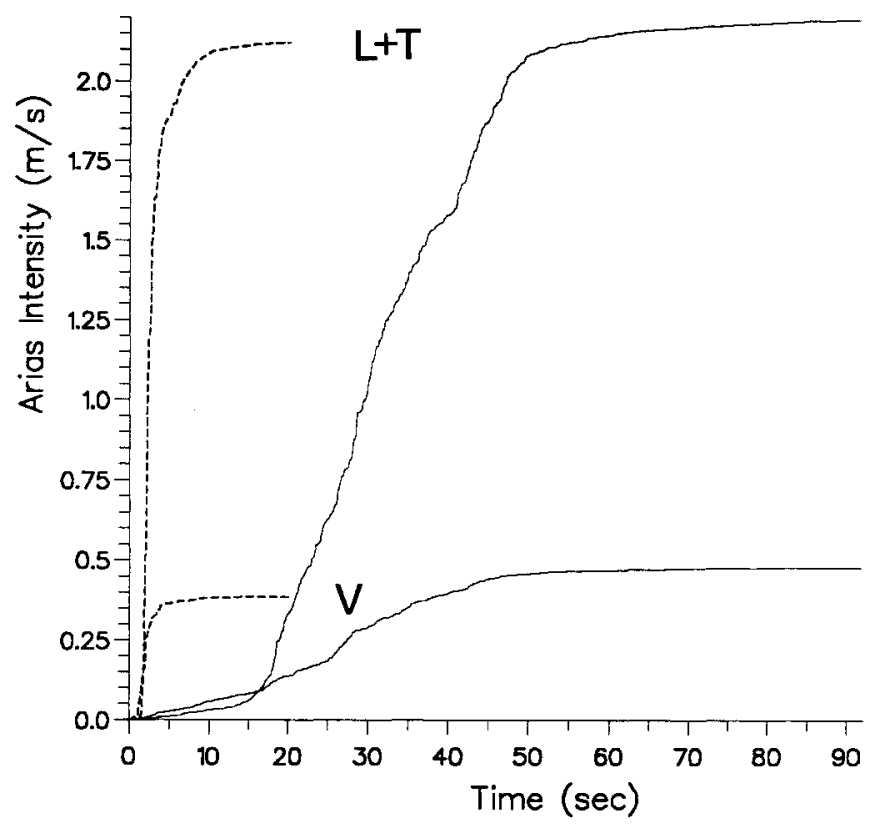

A Figure 6. Plots of Arias intensity from the combined horizontal components of motion and the vertical components (indicated by $V)$ of the two records shown in Figure 5 from 1982 (solid) and 1986 (dashed).

(a)

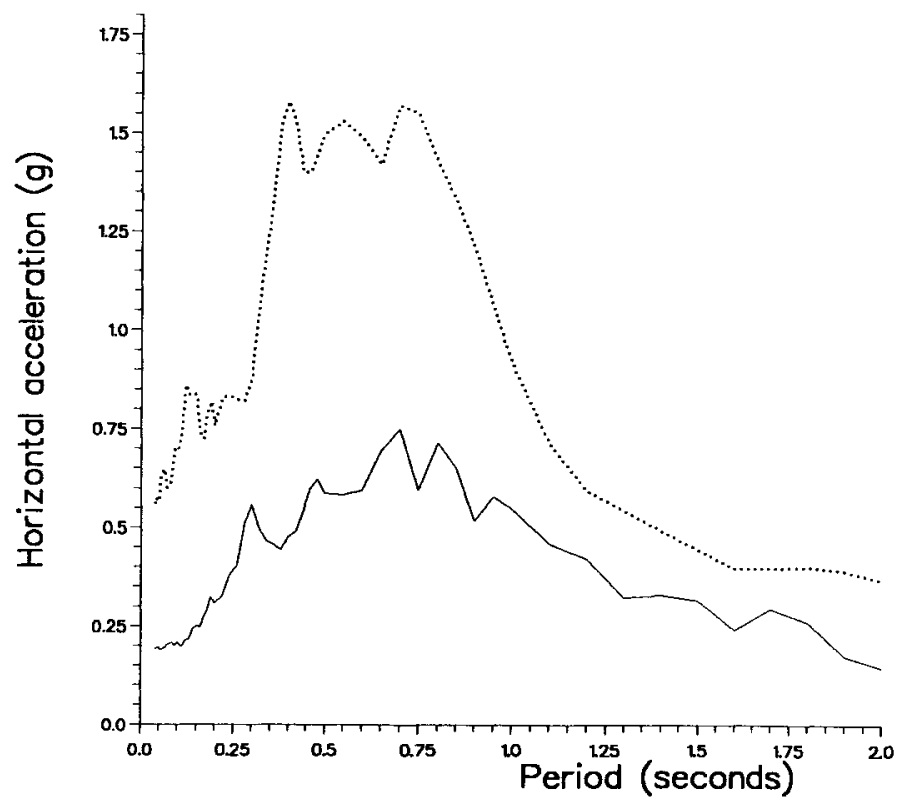

the records in Figure 5 show another interesting feature, which is that for the local volcanic chain events the vertical ground motion can be very important. Following the San Salvador earthquake of 3 May 1965 (Lomnitz and Schulz, 1966), although there was no evidence of strong vertical motions, it was recommended that vertical seismic loads be considered for design since it was possible that such local events could generate significant vertical accelerations (Rosenblueth and Prince, 1966). In the same report, Rosenblueth and Prince (1966) recommended the production of two seismic zoning maps for El Salvador, one for events associated with the subduction zone and the other for earthquakes in the volcanic chain zone. This has not yet been carried out, and clearly the elaboration of such zoning maps and the specification of the associated design spectra will require a significant database of accelerograms from both types of earthquake.

Although an appreciable body of data has now been collected and several of the records have been digitized, there are a number of deficiencies in the distribution of the recordings that need to be addressed. If the strong-motion database is separated according to the seismic source of the generating earthquakes, it is apparent that the number of recordings from volcanic chain events is relatively small. Moreover, the distribution of these data with respect to magnitude and distance is poor, with nearly all the records obtained at epicentral distances of no more than a few kilometers from moderate earthquakes. As a result, it is difficult to obtain a reliable estimate of the attenuation characteristics for volcanic chain earthquakes from the available dataset.

(b)

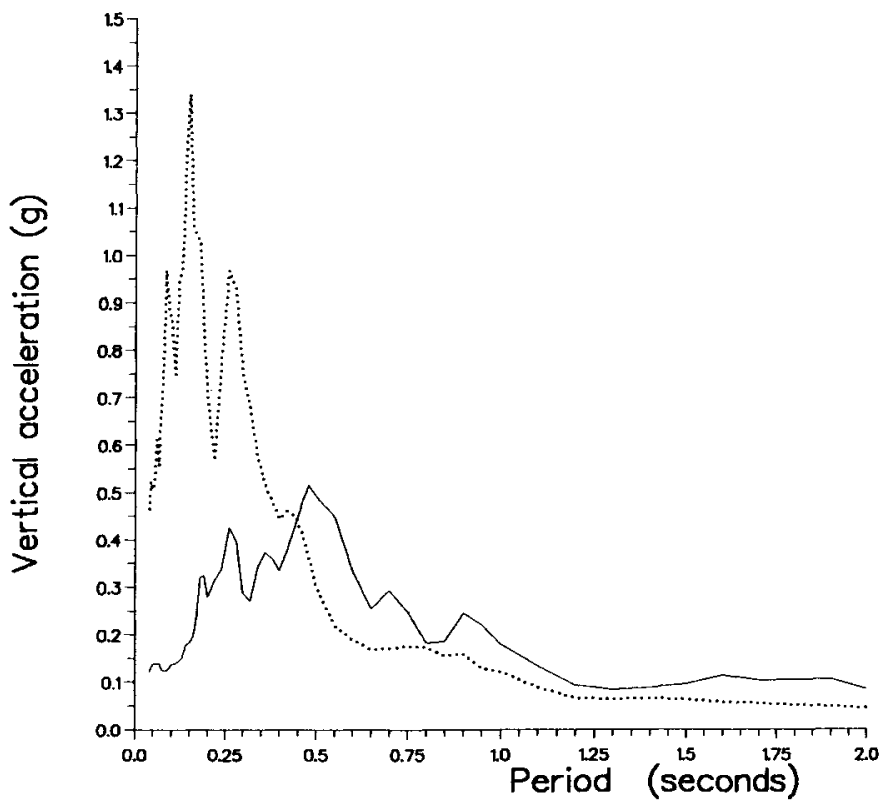

$\Delta$ Figure 7. (a) Horizontal and (b) vertical response spectra (5\% damping) from the records in Figure 5 from 1982 (solid) and 1986 (dashed). The horizontal spectra are the envelopes of the two horizontal components. 


\section{NEW DIGITAL NETWORK}

A network of SMA-1 analog accelerographs is operated in El Salvador by the Centro de Investigaciones Geotécnicas (CIG), which is part of the Ministry of Public Works. This network currently consists of 16 accelerographs distributed throughout El Salvador: four are located within San Salvador in the UCA, the CIG, the Observatorio Sismológico, and in Soyapango, and the others dispersed throughout the country in Acajutla, Ahuachapán, Chalatenango, Comalapa (airport), Curuco, Metapán, San Miguel, Santa Ana, Santa Tecla, Santiago de María, San Vicente and Sensuntepeque, as shown in Figure 8. In addition to these instruments, another eight have been installed as a three-dimensional array within San Salvador, with instruments at ground level and at the bottoms of four wells.

Three SMA-1 strong-motion accelerographs are also operated by the Comisión Ejecutiva Hidroeléctrica del Río Lempa (CEL) on the San Lorenzo (15 de septiembre) Dam on the Lempa River. Two SSA-2 accelerographs have also been installed recently as part of a monitoring network around the geothermal plant recently initiated in Berlín, in the Department of Usulután. Three SMA-1 instruments are also operated by the Camino Real Hotel in San Salvador, apparently the only large building to have fulfilled Article 30 of the 1966 Regulations for Seismic Design that specified that strong-motion instruments should be installed in all buildings with an area exceeding $10,000 \mathrm{~m}^{2}$ or height greater than $45 \mathrm{~m}$. These instruments recorded the ground motion and structural response in the October 1986 earthquake (Shakal et al., 1987).

The new strong-motion network established within this project consists of ten Kinemetrics SSA-2 digital accelerographs, fitted with TCG-2 time-code generators. The network has been given the name TALULIN, which in the indigenous Nahuatl language means earthquake. The instruments have been deployed to provide coverage of seismicity from both the volcanic chain zone and the subduction zone. At the same time, the network is designed to cover different surface geologies in central and southern El Salvador, although the geographical distribution of the instruments was given higher priority and the site geology was only specifically considered to exclude rock outcrop sites. Given that a significant number of records have already been obtained in San Salvador and that the CIG nerwork gives good coverage of the metropolitan area, it was decided to install only one instrument within the capital. For the areas outside San Salvador, it was necessary to identify a large number of possible sites, preferably under the direction and management of a single organization, which could provide secure locations for the stations. An ideal solution was found through the establishment of an agreement with the Ministerio de Salud Pública y Asistencia Social (Health Ministry), which gave access to hospitals and health units

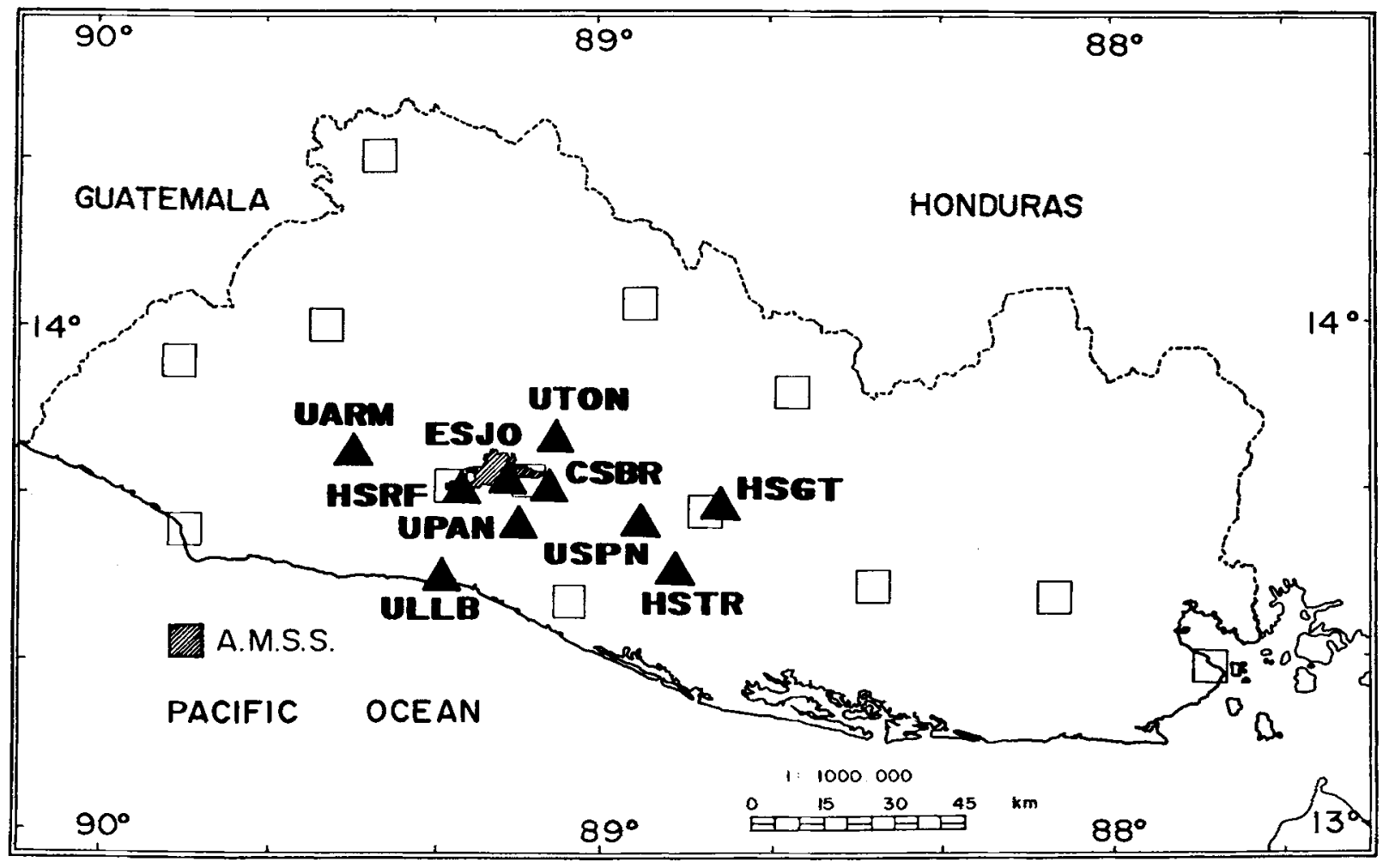

Figure 8. Station locations of new digital network (triangles). Open squares indicate the locations of SMA-1 instruments operated by the Centro de Investigaciones Geotécnicas (CIG). 


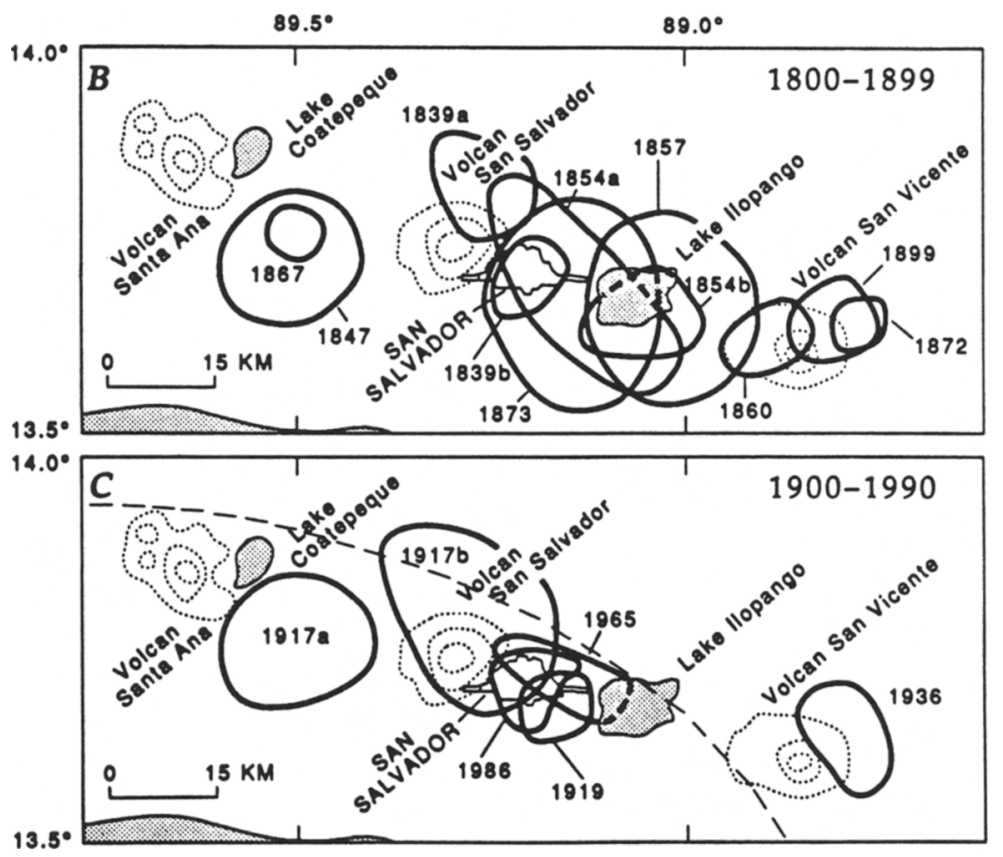

$\Delta$ Figure 9. Maps showing contours of Modified Mercalli intensity $>V I I$ for upper crustal earthquakes in central El Salvador for the periods 1800-1899 and 1900-1990 (Harlow et al., 1993). The dashed line on the lower map shows the MM VII isoseismal associated with the largest subduction event this century, the $M_{s}=7.3$ earthquake that occurred off the coast of El Salvador on 19 June 1982 (Alvarez, 1982).

throughout El Salvador. The agreement was encouraged by the Disasters Unit of the Health Ministry, and part of the agreement is that the UCA will undertake evaluations of the seismic vulnerability of some of the health care establishments.

Priority was given to hospitals rather than health centers because of the better infrastructure and greater security that they can provide. The locations were also chosen to enable reasonably easy access for maintenance of the instruments and data recovery, since despite its small geographical extent, travel in El Salvador is often difficult and time-consuming. The network was designed according to these criteria in order to cover three important sources of seismic activity in the volcanic-chain zone: San Salvador and Lake Ilopango, the area southeast of Lake Coatepeque to the west of San Salvador, and San Vicente to the east of San Salvador (Figure 9). Stations have also been located to the south as far as the coast, and a single station has been placed to the north of San Salvador. The distribution provides coverage of both the subduction zone and the volcanic chain, and in particular will allow recording of volcanic chain earthquakes close to the source and at distances of the order of 10 to 50 kilometers, which will help to resolve the uncertainty associated with the attenuation of strong motion from shallow crustal events. The distribution of the new network is shown in Figure 8. The locations are presented in Table 1; the coordinates have been measured using portable GPS, and the elevations correspond to the closest geodesic benchmarks of the Salvadorean Instituto Geográfico Nacional (IGN). All of the instruments are installed inside structures and at ground level.
In all the stations, the instruments have been set to trigger with an acceleration level of $0.010 \mathrm{~g}$ horizontally or $0.006 \mathrm{~g}$ vertically. The UCA manufactured and installed shelters for each of the accelerographs.

At this stage, detailed information about site conditions is not known, although this information is being recovered from a number of sources, including a few borehole logs available for the actual station sites as well as the logs from water wells drilled by the Administración Nacional de Acueductos y Alcantarrillados (ANDA), several of which are close to the accelerograph stations. This information is presented in full in the first annual report on the operation of the network (Cepeda et al., 1997). It is important to extrapolate such information with caution since the topography of $E l$ Salvador is such that a great deal of construction involves extensive use of landfill, particularly to reclaim steep ravines. The general geological characteristics of the sites presented here are as interpreted from the 1:100,000 geological maps of El Salvador prepared by the Geological Mission of the Bundesantalt für Bodenforschung, Hannover, Germany, and published in 1978 by the IGN in El Salvador; these maps do not provide information about local soil cover. Descriptions of the different formations are also presented by SchmidtThomé (1975), Weyl (1980), and Baxter (1984).

El Salvador consists of four morphological-geological units, which exist as approximately parallel strips running east-west across the country (Weyl, 1980). Along the border with Honduras are the northern mountain ranges, consisting mainly of plutonic rocks from the Tertiary. The historical record suggests that seismic hazard is relatively low in this 


\begin{tabular}{|c|c|c|c|}
\hline \multicolumn{4}{|c|}{$\begin{array}{l}\text { TABLE } 1 \\
\text { Stations characteristics of new digital network }\end{array}$} \\
\hline $\begin{array}{l}\text { Code } \\
\text { S/n } \\
\text { Date }\end{array}$ & Location & $\begin{array}{l}\text { Coordinates } \\
\text { Elevation }\end{array}$ & Type of structure \\
\hline $\begin{array}{l}\text { ESJO } \\
2396 \\
19 / 2 / 96\end{array}$ & $\begin{array}{l}\text { Externado San José } \\
\text { San Salvador }\end{array}$ & $\begin{array}{l}13.707^{\circ} \mathrm{N} \\
89.207^{\circ} \mathrm{W} \\
675 \mathrm{~m}\end{array}$ & $\begin{array}{l}\text { Library of secondary school. One-story annex of two-story reinforced } \\
\text { brick masonry walls. }\end{array}$ \\
\hline $\begin{array}{l}\text { HSRF } \\
2397 \\
23 / 2 / 96\end{array}$ & $\begin{array}{l}\text { Hospital San Rafael } \\
\text { Santa Tecla } \\
\text { La Libertad }\end{array}$ & $\begin{array}{l}13.671^{\circ} \mathrm{N} \\
89.279^{\circ} \mathrm{W} \\
912 \mathrm{~m}\end{array}$ & $\begin{array}{l}\text { Large hospital warehouse. Single-story construction with steel frame } \\
\text { and brick walls. }\end{array}$ \\
\hline $\begin{array}{l}\text { UARM } \\
2404 \\
26 / 2 / 96\end{array}$ & $\begin{array}{l}\text { Unidad de Salud } \\
\text { Armenia, Sonsonate }\end{array}$ & $\begin{array}{l}13.744^{\circ} \mathrm{N} \\
89.501^{\circ} \mathrm{W} \\
570 \mathrm{~m}\end{array}$ & $\begin{array}{l}\text { Storage room in health center. One-story building of reinforced brick } \\
\text { masonry, light roof. }\end{array}$ \\
\hline $\begin{array}{l}\text { ULLB } \\
2398 \\
26 / 2 / 96\end{array}$ & $\begin{array}{l}\text { Unidad de Salud } \\
\text { La Libertad }\end{array}$ & $\begin{array}{l}13.486^{\circ} \mathrm{N} \\
89.327^{\circ} \mathrm{W} \\
16 \mathrm{~m}\end{array}$ & $\begin{array}{l}\text { Storage room in health center. One-story building of reinforced brick } \\
\text { masonry, light roof. }\end{array}$ \\
\hline $\begin{array}{l}\text { HSTR } \\
2402 \\
27 / 2 / 96\end{array}$ & $\begin{array}{l}\text { Hospital Santa Teresa } \\
\text { Zacatecoluca, La Paz }\end{array}$ & $\begin{array}{l}13.517^{\circ} \mathrm{N} \\
88.869^{\circ} \mathrm{W} \\
253 \mathrm{~m}\end{array}$ & $\begin{array}{l}\text { Single story annex of reinforced brick masonry adjacent to } 5 \text {-story RC } \\
\text { frame building. }\end{array}$ \\
\hline $\begin{array}{l}\text { USPN } \\
2399 \\
27 / 2 / 96\end{array}$ & $\begin{array}{l}\text { Unidad de Salud } \\
\text { San Pedro Nonualco } \\
\text { La Paz }\end{array}$ & $\begin{array}{l}13.602^{\circ} \mathrm{N} \\
88.927^{\circ} \mathrm{W} \\
658 \mathrm{~m}\end{array}$ & $\begin{array}{l}\text { Storage room in health center. One-story building of reinforced brick } \\
\text { masonry, light roof. }\end{array}$ \\
\hline $\begin{array}{l}\text { HSGT } \\
2403 \\
28 / 2 / 96\end{array}$ & $\begin{array}{l}\text { Hospital Santa Gertrudis } \\
\text { San Vicente }\end{array}$ & $\begin{array}{l}13.642^{\circ} \mathrm{N} \\
88.784^{\circ} \mathrm{W} \\
373 \mathrm{~m}\end{array}$ & $\begin{array}{l}\text { Storage room in health center. One-story building of reinforced brick } \\
\text { masonry, light roof. }\end{array}$ \\
\hline $\begin{array}{l}\text { CSBR } \\
2395 \\
28 / 2 / 96\end{array}$ & $\begin{array}{l}\text { Centro de Salud } \\
\text { San Bartolo } \\
\text { San Salvador }\end{array}$ & $\begin{array}{l}13.704^{\circ} \mathrm{N} \\
89.106^{\circ} \mathrm{W} \\
622 \mathrm{~m}\end{array}$ & $\begin{array}{l}\text { Storage room in health center. One-story building of RC frame, hollow } \\
\text { brick walls, light roof. }\end{array}$ \\
\hline $\begin{array}{l}\text { UPAN } \\
2401 \\
1 / 3 / 96\end{array}$ & $\begin{array}{l}\text { Unidad de Salud } \\
\text { Panchimalco } \\
\text { San Salvador }\end{array}$ & $\begin{array}{l}13.614^{\circ} \mathrm{N} \\
89.179^{\circ} \mathrm{W} \\
613 \mathrm{~m}\end{array}$ & $\begin{array}{l}\text { Administration office in one-story building of reinforced brick masonry } \\
\text { walls. }\end{array}$ \\
\hline $\begin{array}{l}\text { UTON } \\
2400 \\
11 / 7 / 96^{b}\end{array}$ & $\begin{array}{l}\text { Unidad de Salud } \\
\text { Tonacatepeque } \\
\text { San Salvador }\end{array}$ & $\begin{array}{l}13.778^{\circ} \mathrm{N} \\
89.114^{\circ} \mathrm{W} \\
607 \mathrm{~m}\end{array}$ & $\begin{array}{l}\text { Storage room in health center. One-story building of reinforced brick } \\
\text { masonry, light roof. }\end{array}$ \\
\hline
\end{tabular}

a. Date of installation of the accelerograph.

b. UTON station was not installed until July 1996 due to relocation of Health Center.

part of the country, and none of the instruments are located in this area. The central part of El Salvador is the Great Interior Valley, a heterogeneous basin and low mountain topography; the southern part of the Valley contains the chain of Pleistocene volcanoes, six of which are active. Nearly all of the major cities of El Salvador, and hence most of the population, are located within the Great Interior Valley. To the south of the Valley there are three coastal mountain ranges: the Tacuba in the west on the border with Guatemala, the Balsamo in the central and western area, and the Jucuarán range on the eastern side bordering the Golfo de Fonseca. In between the coastal ranges are the coastal plains in the western and central parts of the country, which consist of alluvial deposits with intercalated pyroclastics, spits, and mangrove swamps.

The UTON station is located within the Great Interior Valley to the north of the axis of the volcanic chain, whereas the ESJO, CSBR, and HSGT stations are located along the volcanic chain. The surface geology at these four sites is tierra blanca, a young, poorly consolidated, volcanic tuff which originated from eruptions within Lake Ilopango during the Holocene.
The station UARM is located on the boundary between the Great Interior Valley and the Balsamo range, and it is also overlain by Holocene volcanic tuff known as tobas color café, which is slightly older than the tierra blanca.

The HSRF station is also situated on the boundary between the Great Interior Valley and the Balsamo range, but in an area of effusive rocks from the Late Pleistocene, which together with the tierra blanca and the tobas color café constitute the San Salvador formation, which is the most recent in the country.

The stations USPN and UPAN are located within the Balsamo range, the former on the northern side close to the volcanic center of Chichontepeque and the latter on the southern side where the mountains descend to the coastal plain. The geology at these two sites consists of pyroclastics and volcanic rocks that belong to the Cuscatlán formation and are associated with acidic and intermediate volcanism during the Pleistocene, which produced ignimbrites on the southern slopes of the Balsamo range.

The HSTR station is located in the coastal plain on the older Balsamo formation, Tertiary pyroclastics and volcanic 


\begin{tabular}{|c|c|c|c|c|c|c|c|c|c|}
\hline \multicolumn{10}{|c|}{$\begin{array}{c}\text { TABLE } 2 \\
\text { Strong-motion records obtained during first six months of operation }\end{array}$} \\
\hline \multirow[b]{2}{*}{ Date } & \multirow{2}{*}{$\begin{array}{l}\text { Time } \\
\text { (UTC) }\end{array}$} & \multirow[b]{2}{*}{$\mathbf{N}^{\circ}$} & \multirow[b]{2}{*}{$\mathbf{w}^{\circ}$} & \multirow[b]{2}{*}{$M^{a}$} & \multirow{2}{*}{$\begin{array}{l}\text { Station } \\
\text { Code }\end{array}$} & \multirow{2}{*}{$\begin{array}{c}d^{b} \\
(\mathrm{~km})\end{array}$} & \multicolumn{3}{|c|}{$a_{\max }(g)$} \\
\hline & & & & & & & $\mathrm{N}-\mathrm{S}$ & Vert & $E-W$ \\
\hline $3-3-96$ & $14: 55$ & 11.77 & 86.93 & $5.4 \mathrm{~B}$ & USPN & 297 & 0.011 & 0.006 & 0.008 \\
\hline \multirow[t]{4}{*}{$3-3-96$} & $16: 37$ & 11.12 & 86.69 & $6.6 \mathrm{~S}$ & HSGT & 360 & 0.013 & 0.009 & 0.016 \\
\hline & & & & & HSTR & 356 & 0.009 & 0.010 & 0.010 \\
\hline & & & & & UARM & 421 & 0.012 & 0.008 & 0.011 \\
\hline & & & & & USPN & 367 & 0.023 & 0.013 & 0.021 \\
\hline $28-5-96$ & $15: 25$ & 13.03 & 89.11 & $4.8 \mathrm{~B}$ & ULLB & 56 & 0.019 & 0.008 & 0.011 \\
\hline \multirow[t]{2}{*}{$30-5-96$} & $14: 27$ & 12.85 & 89.14 & $4.1 \mathrm{~B}$ & USPN & 86 & 0.014 & 0.010 & 0.016 \\
\hline & & & & & HSRF & 92 & 0.014 & 0.009 & 0.021 \\
\hline \multirow[t]{3}{*}{$7-6-96$} & $14: 28$ & 12.71 & 88.11 & $4.9 \mathrm{~B}$ & USPN & 133 & 0.011 & 0.012 & 0.016 \\
\hline & & & & & HSGT & 127 & 0.012 & 0.006 & 0.010 \\
\hline & & & & & HSTR & 121 & 0.009 & 0.008 & 0.010 \\
\hline \multirow[t]{3}{*}{$7-7-96$} & $23: 47$ & 12.8 & 88.7 & $4.3 \mathrm{D}$ & USPN & 92 & 0.008 & 0.006 & 0.006 \\
\hline & & & & & HSGT & 94 & 0.008 & 0.008 & 0.009 \\
\hline & & & & & HSTR & 82 & 0.016 & 0.009 & 0.016 \\
\hline \multirow[t]{2}{*}{$18-7-96$} & $05: 22$ & 12.99 & 88.54 & $4.5 \mathrm{~B}$ & USPN & 80 & 0.016 & 0.010 & 0.013 \\
\hline & & & & & HSTR & 68 & 0.016 & 0.009 & 0.012 \\
\hline \multirow[t]{9}{*}{$22-7-96$} & $08: 30$ & 12.94 & 88.91 & $5.5 \mathrm{~B}$ & UARM & 110 & 0.027 & 0.023 & 0.032 \\
\hline & & & & & CSBR & 87 & 0.020 & 0.011 & 0.015 \\
\hline & & & & & ULLB & 75 & 0.048 & 0.018 & 0.027 \\
\hline & & & & & USPN & 73 & 0.031 & 0.023 & 0.028 \\
\hline & & & & & HSRF & 90 & 0.021 & 0.013 & 0.027 \\
\hline & & & & & UTON & 95 & 0.021 & 0.014 & 0.018 \\
\hline & & & & & HSGT & 78 & 0.022 & 0.015 & 0.023 \\
\hline & & & & & ESJO & 91 & 0.015 & 0.016 & 0.013 \\
\hline & & & & & HSTR & 64 & 0.014 & 0.009 & 0.013 \\
\hline
\end{tabular}

a. Magnitude: $\mathrm{S}-M_{s}, \mathrm{~B}-m_{b}, \mathrm{D}-M_{D}$.

b. Epicentral distance.

rocks, which in many locations are overlain by thick covers of red soils.

The station ULLB is located on the coast to the south of the Bálsamo range on Quaternary sedimentary deposits which are part of the San Salvador formation.

In the light of the lack of agreement on the classification of site conditions in attenuation studies and the preliminary nature of these data, no attempt is made to classify the sites as "rock" or "soil" until further investigations have been carried out.

\section{PRELIMINARY RESULTS}

The new accelerograph network was tested almost immediately after installation by an earthquake that occurred on 3 March 1996, two days after the last instrument had been placed in Panchimalco. The earthquake occurred off the coast of Nicaragua with a magnitude reported as $M_{s} 6.6$ and was widely felt in El Salvador. Of the nine stations operational at the time of the earthquake, four were triggered: UARM, HSTR, USPN and HSGT. The five stations that did not trigger were all checked and found to be functioning identically to those that triggered, with the exception of ESJO, which at the time had been initially set with the trigger characteristics of an SMA-1 $(0.01 \mathrm{~g}$ vertical acceleration). The station USPN also recorded a smaller event that occurred about an hour and a half earlier, located in the same general area and for which the NEIC reports a magnitude of $m_{b} 5.4$, which was also widely felt throughout south and eastern El Salvador.

During the first six months of operation of the network (until the end of August, 1996), a total of 25 records were generated by eight earthquakes, and all but one (UPAN) of the stations have been triggered at least once. The characteristics of the records obtained are given in Table 2 . All of these records have been triggered by earthquakes associated with 


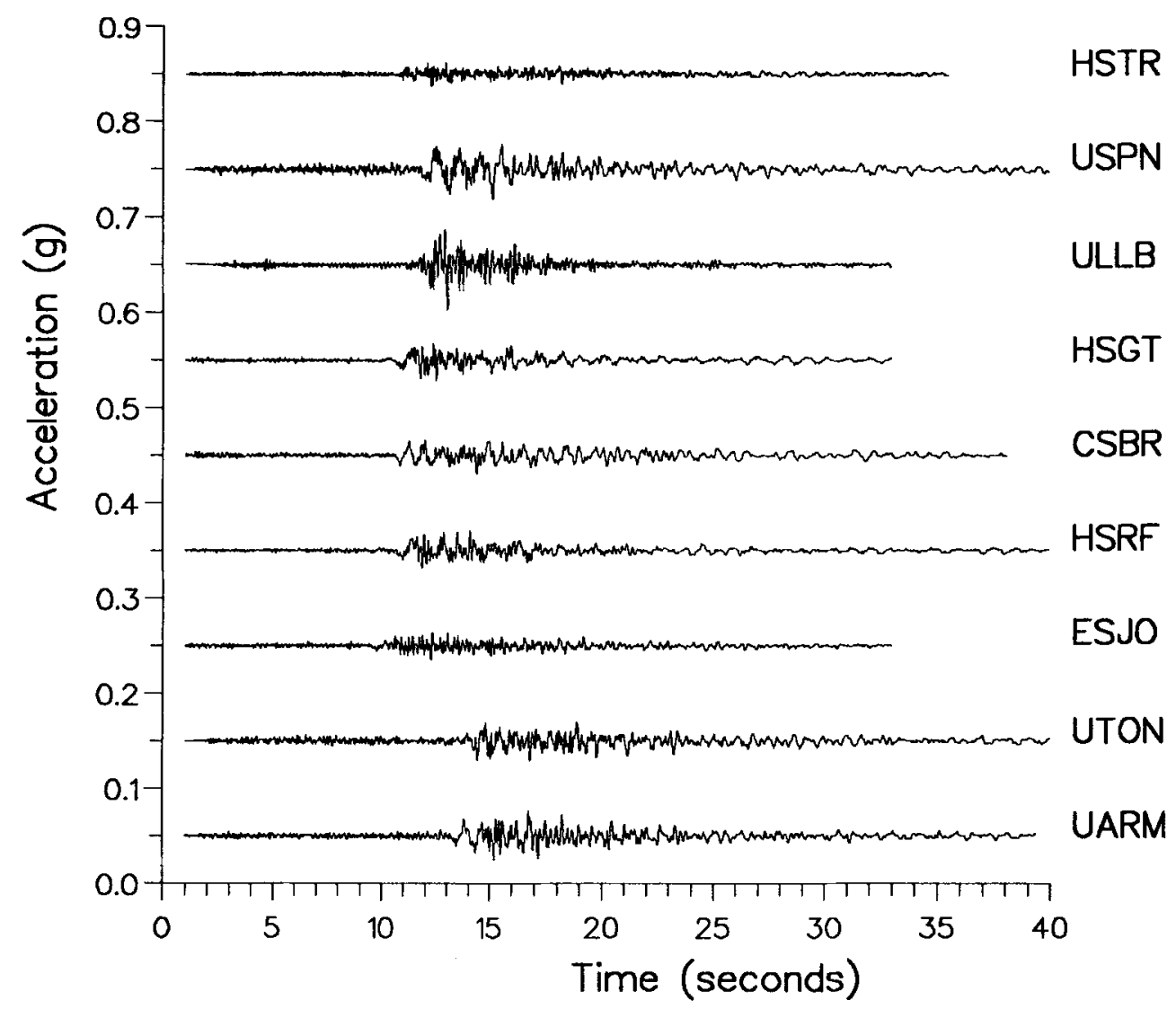

A Figure 10. Acceleration time histories recorded by the new network on 22 July 1996 . The NS component of each record is shown.

the subduction zone, and their hypocenters are all located offshore with reported focal depths between 30 and $80 \mathrm{~km}$. Figure 10 shows the N-S components of the acceleration time-histories recorded on 22 July 1996. The time scale is only relative since there were problems with the absolute times recorded by the TCG-2. The records have been arranged in order of increasing epicentral distance, and the influence of the local site conditions is immediately apparent.

In order to make some inferences regarding the site conditions, we have employed the spectral ratio method used by Theodulidis and Bard (1995), plotting the ratio of horizontal to vertical amplitudes of the Fourier spectra as a function of frequency (Nakamura ratio). The method is based on the assumption that the horizontal motion may be amplified by the presence of soil layers but that vertical motion is not, hence the ratio of the two should represent the influence of the soil layers or other sites effects. Figure 11 shows the ratios obtained from the average of $(a)$ seven recordings at San Pedro Nonualco (USPN) and (b) five recordings at Zacatecoluca (HSTR); in both cases the ratios have been first smoothed by 50 passes of a 3-point running average and then the averages of the ratios from each record determined.

Both of the stations show clear amplification in certain frequency ranges which may reflect the influence of soil layers at the sites. Both records show some peaks at frequencies of about $7-8 \mathrm{~Hz}$, which could reflect thin soil layers. The excep- tionally narrow peaks observed on the USPN record may be related to topography; this station is located atop a narrow and elongated ridge, oriented approximately E-W, and it is possible that the apparent amplification of motion at this site is mainly due to topographical effects. As further records are obtained, these characteristics will be explored further and correlated with the geotechnical data. The importance of soil deposits in El Salvador, particularly poorly consolidated volcanic tuffs such as the tierra blanca in the capital, in amplifying earthquake motions has been the focus of several studies (Rymer, 1987; Faccioli et al., 1988; Atakan and Torres, 1994). The long-term objectives of this research include the microzonation of the main urban centers in El Salvador, particularly those that lie within the relatively small zones that are strongly affected by volcanic chain earthquakes. $\mathbf{z}$

\section{ACKNOWLEDGMENTS}

We are particularly indebted to the following individuals for their generous cooperation in facilitating the establishment of the new strong-motion network: P. Anibal Meza, S.J., Rector of the Externado San José; and in the Ministerio de Salud Pública y Asistencia Social, Dr. Eduardo Interiano, Health Minister; Dra. Ana María Alfaro de Gamero, ViceMinister of Health; Dr. Manuel Enrique Angulo, General Director; Dra. Dyna de Navarro, Sub-director of Preventa- 
(a)

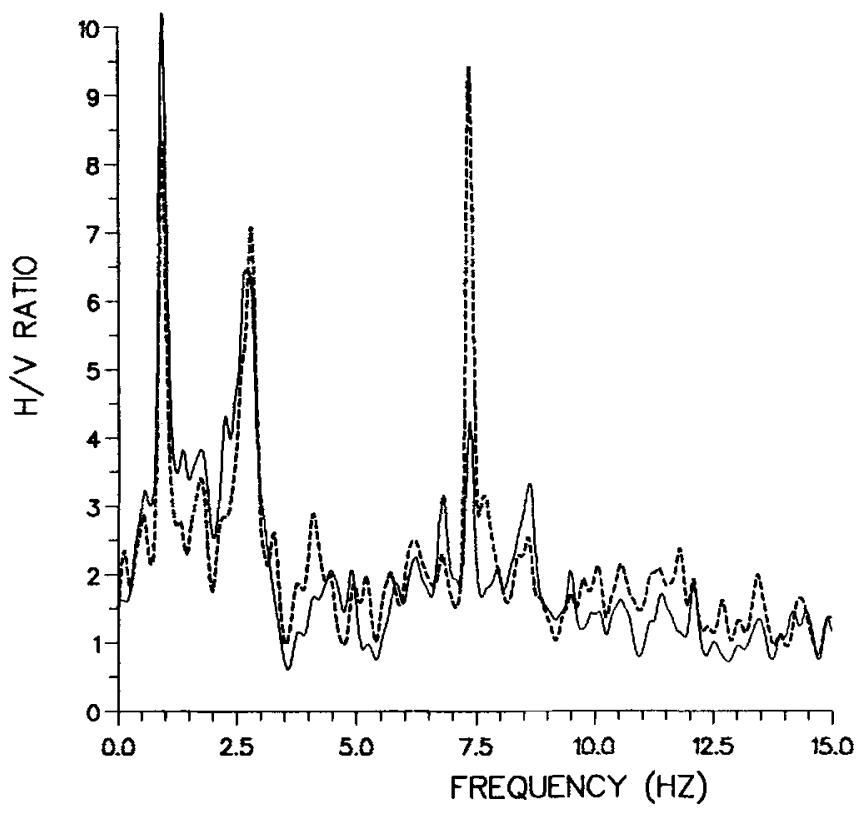

(b)

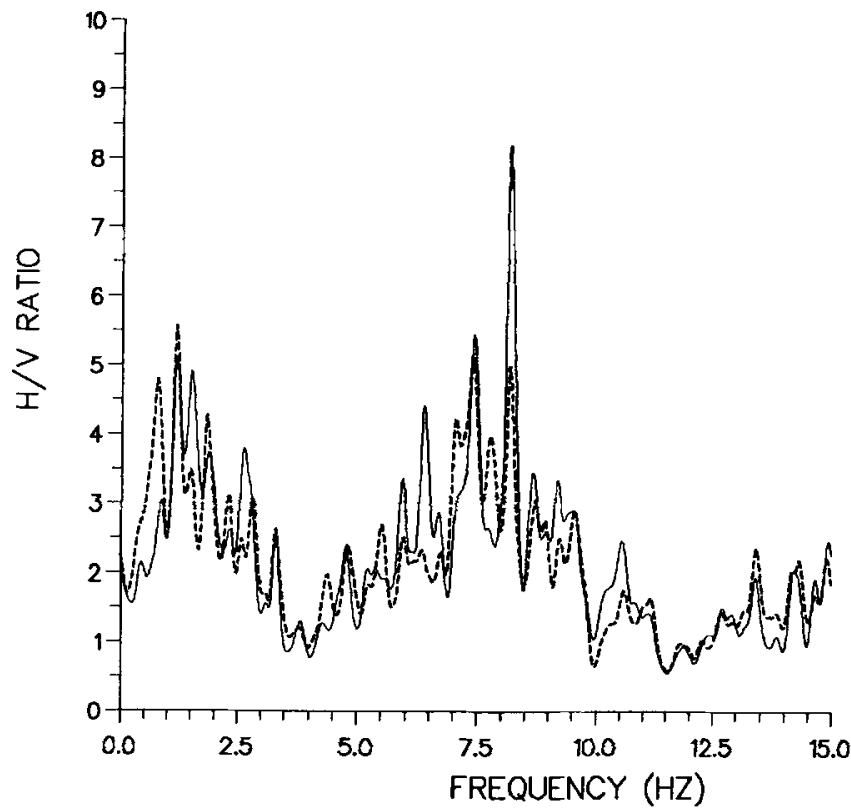

$\Delta$ Figure 11. Ratios of horizontal to vertical Fourier amplitude spectra (Nakamura ratios) for the (a) seven recordings from USPN and (b) five recordings from HSTR stations. The solid lines represent the NS components and the dashed lines the EW.

tive Medicine; Dr. Odilio Alcides Linares, Chief of Environmental Attention; Dra. Patricia de Quinteros, Sub-director of Primary Health Care; Dra. Estela Parada, Sub-director of Hospitals; and nuestro angel Lic. Gloria de Calles, National Coordinator of the Disasters Unit, whose enthusiasm, efficiency, and energy have been critical in making this cooperation possible. We would also like to thank all those members of staff in the hospitals and health units who allowed us to interrupt their busy schedules and generously assisted us in many different ways. We are also grateful for the cooperation of the Centro de Investigaciones Geotécnicas, especially the Chief of the Department of Seismological Research, Ing. Douglas Hernández, and Ing. Rodolfo Torres. We are also highly indebted to Mauricio Ciudad Real, Ogie Kuraica, Rudy Díaz, Enrique Guevara Ortíz, and Mark Sereci from Kinemetrics Inc., who have provided invaluable support and assistance. Thanks are also due to Karla Rodríguez for her assistance with the illustrations. The research project has been supported by the National Council for Science and Technology (CONACYT) in El Salvador. This project is supported by CEC contract CI1*-CT940104 (DG12 HSMU).

\section{REFERENCES}

Alfaro, C.S., A.S. Kiremidjian, and R.A. White (1990). Seismic zoning and ground motion parameters for El Salvador, Report No.93, The John A. Blume Earthquake Engineering Center, Stanford University.

Algermissen, S.T., S.L. Hansen, and P.C. Thenhaus (1988). Seismic hazard evaluation for El Salvador, Report for the US Agency for International Development, $21 \mathrm{pp}$.
Alvatez, G., S. de J. (1982). Informe técnico sobre aspectos sismológicos del terremoto en El Salvador del 19 de junio de 1982, Centro de Investigaciones Geotécnicas, Ministerio de Obras Públicas, San Salvador.

Ambraseys, N.N. and R.D. Adams (1996). Large Central American earthquakes 1898-1994, Geophys. J. Int., 127, 665-692.

Atakan, K. and R. Torres (1994). Local site response in San Salvador, El Salvador, based on the October 10, 1986 earthquake, Reduction of Disasters in Central America Report No. 6, Institute of Solid Earth Physics, University of Bergen.

Baxter, S. (1984). Léxico estratigráfico de El Salvador, Comisión Ejecutiva Hidroeléctrica del Río Lempa, San Salvador.

Bommer, J. (1996). Terremotos, urbanización y riesgo sísmico en San Salvador, PRISMA, Boletin No. 18, San Salvador.

Bommer, J. and S. Ledbetter (1987). The San Salvador earthquake of 10th October 1986, Disasters, 11, 2, 83-95.

Bommer, J.J., D.A. Hernández, J.A. Navarrete, and W.M. Salazar (1996). Seismic hazard assessments for El Salvador, Geofisica Internacional, 35, 227-244.

Cepeda, J.M., W.M. Salazar, and J.J. Bommer (1997). Informe anual de la red acelerográfica TALULIN marzo 1996-febrero 1997, Universidad Centroamericana, San Salvador.

Coburn, A. and R. Spence (1992). Earthquake Protection, Wiley, Chichester, England.

Dewey, J.W. and G. Suarez (1991). Seismotectonics of Middle America, in Slemmons et al., eds. Neotectonics of North America, Geological Society of America Decade Map, vol. I, 309-321.

Dahle, A., A. Climent, W. Taylor, H. Bungum, P. Santos, M. Ciudad Real, C. Lindholm, W. Strauch, and F. Segura (1995). New spectral strong-motion attenuation models for Central America, Proceedings, Fifth International Conference on Seismic Zonation, Nice, vol. II, 1005-1012.

Faccioli, E., C. Battistella, P. Alemani, and A. Tibaldi (1988). Seismic microzoning investigations in the metropolitan area of San Salvador, El Salvador, following the destructive earthquake of October 10, 1986, Proceedings, International Seminar on Earthquake Engineering, Innsbruck, 28-65. 
Güendel, F. and H. Bungum (1995). Earthquakes and seismic hazard in Central America, Seism. Res. Lett., 66, 5, 19-25.

Harlow, D.H., R.A White, M.J. Rymer, and S. Alvarado G. (1993). The San Salvador earthquake of 10 October 1986 and its historical context, Bull. Seism. Soc. Am., 83, 4, 1,143-1,154.

Lara, M.A. (1983). The El Salvador earthquake of June 19, 1982, EERI Newsletter, 17, 1, January 1983, 87-96.

Lindholm, C., W. Rojas, H. Bungum, A. Dahle, E. Camacho, H. Cowan, and M. Laporte (1995). New regional seismic zonation for Central America, Proceedings, Fifth International Conference on Seismic Zonation, Nice, vol. I, 437-444.

Lomnitz, C. and R. Schulz (1966). The San Salvador earthquake of May 3, 1965, Bull. Seism. Soc. Am., 56, 561-575.

Olson, R.A. (1987). The San Salvador earthquake of October 10, 1986-overview and context, Earthquake Spectra, 3, 415-418.

Rojas, W., H. Cowan, C. Lindholm, A. Dahle, and H. Bungum (1993). Regional seismic zonation for Central America: a preliminary model, NORSAR Technical Report No.2-12,39 pp.

Rosenblueth, E. and J. Prince (1966). El temblor de San Salvador, 3 de mayo 1965: ingeniería sísmica, Ingenieria, 36,1, 31-58, UNAM, Mexico.

Rymer, M.J. (1987). The San Salvador earthquake of October 10, 1986-geologic aspects, Earthquake Spectra, 3, 435-463.

Schmidt-Thomé, M. (1975) The geology in the San Salvador area (El Salvador, Central America), a basis for city development and planning, Geologisches Jahrbuch, 13, 207-228.

Shakal, A.F., M. Moh-jiann Huang, and R. Linares (1987). The San Salvador earthquake of October 10, 1986-processed strong motion data, Earthquake Spectra, 3, 465-481.

Singh, S.K., C. Gutíerrez, J. Arboleda, and M. Ordaz (1993). Peligro sísmico en El Salvador. Universidad Nacional Autónoma de México.

Theodulidis, N.P. and P.-Y. Bard (1995). Horizontal to vertical spectral ratio and geological conditions: an analysis of strong motion data from Greece and Taiwan (SMART-1), Soil Dynamics and Earthquake Engineering, 14, 177-197.

Weyl, R. (1980). Geology of Central America, Gebruider Borntraeger, Berlin.

White, R.A. (1991). Tectonic implications of upper-crustal seismicity in Central America, in Slemmons et al., eds. "Neotectonics of North America," Geological Society of America Decade Map, vol. I, 323-338.
White, R.A. and D.H. Harlow (1993). Destructive upper-crustal earthquakes of Central America since 1900, Bull. Seism. Soc. Am., 83, 1,143-1,154.

White, R.A. and D.H. Harlow (1993). Destructive upper-crustal earthquakes of Central America since 1900, Bull. Seism. Soc. Am., 83, $1,115-1,142$.

Civil Engineering Dept. Imperial College

London SW7 2BU, UK e-mail: j.bommer@ic.ac.uk (J.J.B., N.N.A.)

Universidad Complutense de Madrid Departamento de Geofisica 28040 Madrid, Spain (A.U., E.B.)

Universidad Centroamericana "José Simeón Cañas" A.P. (Cl) 168, San Salvador, El Salvador (J.M.C., J.C.H., W.M.S., J.C., P.M.)

Instituto Geográfico Nacional General Ibanez de Ibero 3, 28003

Madrid, Spain (A.S., J.M.)

Institut du Physique de Globe Department de Sismologie Rue Place Jussieu 4 75252 Paris CX 05, France (R.M.)

National Technical University Laboratory for Earthquake Engineering Zegrafos, 15700 Athens Greece (D.P.) 